\title{
INTAS plans improved grant systems after claims of 'patronage'
}

Brussels. INTAS, the European organization that supports research projects in New Independent States (NIS) of the former Soviet Union, is to streamline its procedures for handling grant applications in order to meet criticism that it is too bureaucratic, too slow and too secretive.

Pierre Venet, the general secretary, told the general assembly of INTAS in Brussels last week that mechanisms are being set up to ensure that money is transferred to the NIS scientists safely and quickly, and that a full list of approved projects will soon be made available.

He also promised that procedural guidelines for the Council of Scientists, the body responsible for recommending which projects are funded, will be provided before the next call for proposals at the end of this year and that these will stipulate that council members must not be involved in INTAS projects. Concern had been expressed at the assembly about rumours that some members of the council had either received or been personally linked to a large number of approved projects.

Niceas Schamp, the chairman of the council and an organic chemist from Gent in Belgium, denies that this has been the case. But a list of the number of projects with which council members are directly associated indicates that two members have links with 53 and 37 projects respectively.

Both INTAS and the European Commission (EC), which chairs the assembly and provides most of the funding for the programme, deny that patronage by some council members has skewed the allocation of grants - and they are concerned by rumours that this has happened.

In addition, they point out, for example, that those individuals concerned are world renowned scientists, and that it was therefore not surprising that they were appointed to the council and were successful in winning grants.

But Annalise Eggimann, Swiss representative to the INTAS assembly, says that both INTAS and the commission should indicate that the critics, who include individuals inside both the commission and INTAS, are being taken seriously by providing statistics on the involvement of council members in projects.

Concern was also reflected in the decision taken by the INTAS assembly to select new members of the committee before the next call for proposals.

Alison Abbott

\section{Nuclear watchdog tightens incident reporting rules}

Washington. Suspicious incidents involving radioactive materials in research laboratories would have to be reported at once to the Nuclear Regulatory Commission (NRC) under a new rule proposed by the nuclear watchdog agency.

The NRC wants to be informed within 24 hours of "any intentional, or suspected intentional, diversion of radioactive material from its intended or authorized use". Unlike existing regulations, the new rule is

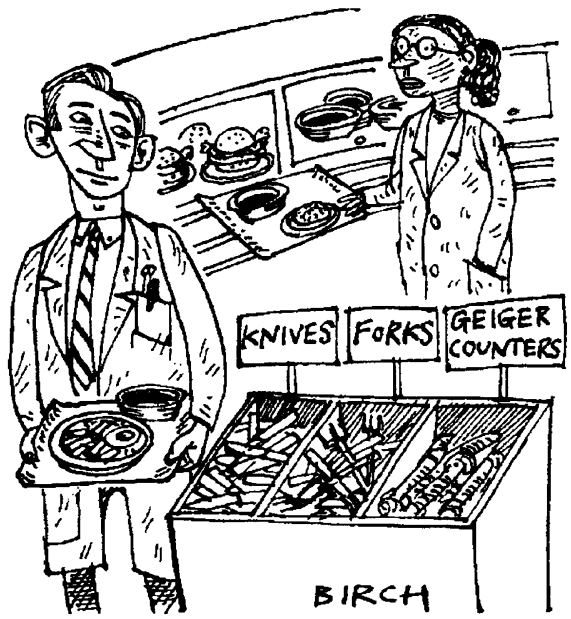

intended to 'catch' incidents that cause very small radiation exposures - or even the hypothetical risk of such an exposure.

The agency said it was proposing the rule because of two incidents last year - one at the National Institutes of Health (NIH) in Bethesda, Maryland, the other at the Massachusetts Institute of Technology (MIT) - in both of which researchers from China ingested sizeable amounts of phosphorous32 , a common radioactive tracer. No satisfactory explanation has yet been found for

\section{Ministry 'knew high risk'}

Tokyo. A three-day search in Japan's Ministry of Health and Welfare has proved what the government has previously refused to admit, namely that in 1983 , the ministry was already aware of a strong possibility that the infectious agent causing AIDS is transmitted through blood and bodily fluids.

The search was ordered by Naoto Kan, Japan's minister of health, soon after he took office last month in the new cabinet of Prime Minister Ryutaro Hashimoto. On 25 January, 72 people, including HIVinfected haemophiliacs, filed a law-suit with the Tokyo District Public Prosecutor's office accusing a former ministry official, Atsuaki Gunji, of perjury in earlier court hearings, when he said that he had been unaware in 1983 of the likely similarity of the infection routes of the AIDS-causing either of the incidents, which are still under criminal investigation by the Federal Bureau of Investigations (FBI) and the NRC.

The NRC was informed immediately of the NIH incident. But it learned of the second incident from MIT only six weeks after the event, when the story was about to break in the media (see Nature 377, 568; 1995). In each case, the dose of radiation received by the victim fell slightly below 600 rems, the level at which the laboratory was obliged to alert the NRC under old rules.

Joe Gilliland, a spokesman for the NRC, said last week that the agency "might have been able to get on top of the situation a little earlier" if it had been informed of the MIT incident at once. "A lesson we learned there was that we needed to sharpen up our reporting practices," he said. NIH did report its incident the day after it happened, Gilliland added; but "there was a question of whether it was required to do so" under the old rules.

The proposed rule was published in the Federal Register on 31 January and interested parties have until 1 March to comment on it. The two apparently unrelated incidents have already resulted in sharp crackdowns by the NRC at both NIH and MIT. Many researchers are irritated by constraints - now strictly enforced - on access to radioactive tracers and the rooms in which they are used, and on eating and drinking in these rooms.

Last December, a report from the Institute of Medicine said the NRC should be stripped of responsibility for regulating radioactive materials in medicine and in biomedical laboratories. The report argued that the NRC did not understand how medicine worked.

Colin Macilwain agent and hepatitis B virus (see Nature 379, 388; 1996)

The group claimed to have a copy of a document submitted to the ministry's AIDS study group in July 1983 that proved their accusation. But the ministry said at first it could not confirm this paper's authenticity as it had lost all such documents. Records of the AIDS study group meetings have now been found in the ministry library. They reportedly state that the causative agent of AIDS is "highly likely transmitted via blood and other bodily fluids"

Announcing the find last week, Kan said that the documents support claims that the ministry was aware of the infection route, and therefore bears some responsibility for the infection of thousands of haemophiliacs in Japan with HIV. 